\title{
PERANCANGAN WEB PAGES INFORMASI PROGRAM BERITA DAN ACARA TVRI STASIUN ACEH
}

\author{
Hendra Saputra \\ Mahasiswa Program Studi Manajemen Informatika, Fakultas Ilmu Komputer, \\ AMIK Indonesia, Jl. T Nyak Arief Sp Mesra No. 400, Kota Banda Aceh, Indonesia \\ Email: hendra.saputra_genk@gmail.com
}

\begin{abstract}
Abstrak
Tujuan penelitian yaitu untuk mengetahui dan merancang sistem informasi program berita dan acara pada TVRI Stasiun Aceh dengan bahasa pemrograman HTML, PHP, CSS, JSON, AJAX dan MySQL sebagai pendukung database. Secara garis besar penelitian ini dibagi dalam tiga tahapan, yaitu pengumpulan data pra pengembangan, pengembangan serta implementasi, dan pengumpulan data pasca Pengembangan Sedangkan dalam pengembangan perangkat lunak menggunakan metode DSRM (Design Science Research Method). Sistem informasi program berita dan acara dilakukan oleh salah seorang staf administrasi bidang program berita dan acara untuk mencatat dan menginput data informasi program berita dan acara. Dari hasil penelitian dapat disimpulkan bahwa Sistem informasi program berita dan acara pada TVRI Stasiun Aceh sudah mengikuti prosedur dengan menggunakan bahasa pemrograman HTML, PHP, CSS, JSON, AJAX dan MySQL sebagai pendukung database.
\end{abstract}

Kata Kunci: Perancangan; Web Pages; Informasi; Program Berita; Acara; TVRI Stasiun Aceh.

\begin{abstract}
The purpose of this research is to identify and design an information system for news and program programs at TVRI Aceh Station using HTML, PHP, CSS, JSON, AJAX and MySQL programming languages as database support. Broadly speaking, this research is divided into three stages, namely predevelopment data collection, development and implementation, and post-development data collection. While in software development using the DSRM (Design Science Research Method) method. The news and event program information system is carried out by one of the administrative staff of the news and events program to record and input data on news and event program information. From the results of the study it can be concluded that the news and program information system at TVRI Aceh Station has followed the procedure using HTML, PHP, CSS, JSON, AJAX and MySQL programming languages as database support.
\end{abstract}

Keyword: Design; Web Pages; Information; News Programming; Event; TVRI Aceh Station. 


\section{Pendahuluan}

Media massa merupakan suatu alat yang berfungsi untuk menyampaikan informasi, saluran pendidikan, hiburan, dan lain sebagainya $[1,2,3]$. Selain itu, media massa juga memberikan efek yang luas terhadap khalayak, di luar fungsi tersebut. Efek media massa tidak hanya memengaruhi sikap seseorang, namun juga dapat memengaruhi perilaku [4,5]. Bahkan dalam tataran yang lebih jauh lagi mungkin media massa dapat memengaruhi sistem-sistem social [6], maupun sistem budaya masyarakat [7], baik dalam waktu yang relatif pendek maupun dalam waktu yang lama [8,9]. Di mana dalam hal ini bisa terjadi karena efek dari media massa yang terjadi secara disengaja maupun tidak disengaja oleh khalayak.

Stasiun Televisi lokal memuat materi program acara televisi yang bersifat lokal atau kedaerahan $[10,11]$. Program acaranya juga menyesuaikan tentang keadaan masyarakat lokal, kebudayaan daerah, dan perkembangan yang terjadi di daerah tersebut $[12,13]$. Salah satu televisi lokal yang ada di Aceh adalah TVRI Stasiun Aceh. Program acara yang ada di TVRI Stasiun Aceh cukup bervariatif [14]. Terdapat berbagai macam program acara berita informasi dan hiburan. Salah satu program acara yang menarik dalam mata acara di TVRI Stasiun Aceh adalah program acara seni dan budaya, dimana program ini merupakan perpaduan antara hiburan dan informasi [15].

Persaingan program acara televisi yang sangat ketat antara stasiun televisi satu dengan stasiun televisi lainnya [16], membuat setiap program acaranya juga harus mempunyai kelebihan dan keunggulan untuk bisa mempertahankan pemirsa televisi agar tetap setia dan loyal pada suatu program acara $[17,18]$. Hal yang menarik dari program acara TVRI Stasiun Aceh adalah perpaduan antara unsur hiburan serta informasi yang disuguhkan. Perpaduan hiburan dan informasi yang membedakan acara TVRI Stasiun Aceh dengan acara lainnya, oleh karena itu dari latar belakang di atas, penulis tertarik untuk melakukan penulisan tentang bagaimana strategi kreatif yang diterapkan pada program acara TVRI Stasiun Aceh. Pemirsa televisi memerlukan sebuah acara televisi yang menarik, oleh karena itu setiap stasiun televisi melakukan berbagai strategi kreatif untuk mempertahankan program acara televisi.

Dengan permasalahan di atas, maka Penulis tergerak untuk mengadakan penelitian pada tempat tersebut dan membuat suatu Sistem Informasi untuk mengatasi permasalahan-permasalahan yang terjadi. Penulis juga akan berusaha secara maksimal untuk mengembangkan sistem informasi tersebut menjadi lebih baik dan efektif dengan sistem komputerisasi dan dapat bermanfaat bagi TVRI Stasiun Aceh. Dari uraian diatas maka yang menjadi tujuan penelitian yaitu untuk mengetahui dan merancang sistem informasi program berita dan acara pada TVRI Stasiun Aceh dengan bahasa pemrograman HTML, PHP, CSS, JSON, AJAX dan MySQL sebagai pendukung database.

\section{Metode Penelitian}

Pengumpulan data yang diperlukan dalam penulisan penelitian ini diperoleh dengan dua metode yaitu studi kepustakaan yang berkaitan dengan literatur-literatur buku-buku perpustakaan dan karya ilmiah lainnya, studi lapangan dengan melaksanakan interview dan observasi langsung terhadap objek yang berhubungan dengan penelitian ini $[19,20,21]$. Secara garis besar penelitian ini dibagi dalam tiga tahapan, yaitu pengumpulan data pra pengembangan, pengembangan serta implementasi, dan pengumpulan data pasca Pengembangan [22,23]. Sedangkan dalam pengembangan perangkat lunak menggunakan metode DSRM (Design Science Research Method) [24]. Adapun penjelasan detail untuk tahapan penelitian adalah seperti dijelaskan pada gambar 1 berikut. 


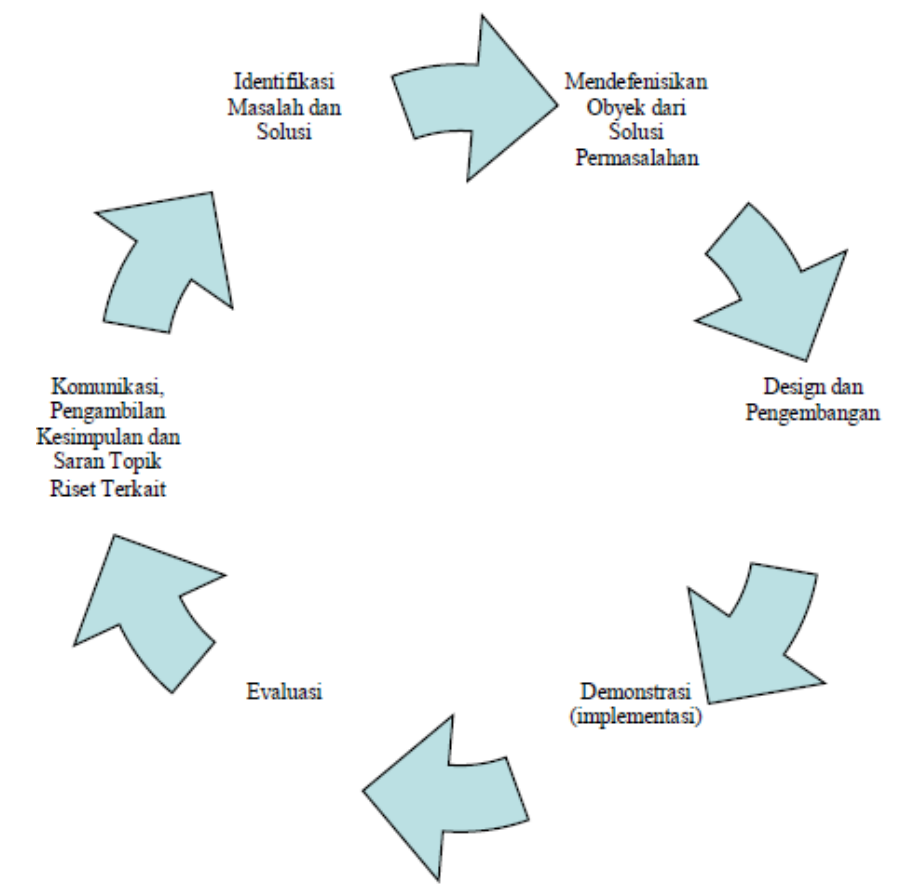

Gambar 1. Metode DSRM (Design Science Research Method) [24].

\section{Hasil dan Pembahasan}

Sistem yang akan dibangun adalah suatu sistem yang memanfaatkan komputer sebagai perangkat utama pemrosesan [25]. Manusia bertindak sebagai pengatur, pengoperasi, serta pengendali utama perangkat tersebut [26, 27]. Cara kerja sistem baru merupakan suatu pengembangan dari cara kerja sistem yang lama [28]. Sistem informasi yang dibangun ini nantinya diharapkan mampu mempersingkat waktu dalam menghasilkan laporan rekap biaya dan rekap program dan acara. Serta membuat penyimpanan dan pengelolaan program dan acara menjadi lebih terstruktur lagi. Ada tiga tahapan utama dalam sistem informasi program dan acara ini, yaitu input data, proses dan data keluaran.

Dalam menganalisa suatu kelemahan yang ada di sistem dapat diidentifikasi dan dievaluasi dari beberapa segi. Berikut merupkan Analisis Kelemahan Sistem untuk Sistem Informasi Program dan acara TVRI Stasiun Aceh yang lama dengan pendekatan -pendekatan sebagai berikut :

a. Volume pekerjaan

Pada sistem yang lama terjadi banyaknya pekerjaan yang dibebankan kepada Staff TVRI Stasiun Aceh yang dapat mengakibatkan tidak lancarnya sistem tersebut.

b. Keandalan

Sistem informasi pengelolaan program dan acara yang lama Staff TVRI Stasiun Aceh dalam setiap pengolahan datanya masih menggunakan manual sehingga tingkat kesalahan sangat tinggi.

c. Teknologi

Sistem informasi pengelolaan program dan acara yang lama kurang memanfaatkan teknologi yang ada. Karena sistem yang lama menggunkan sistem manual dalam setiap pengolahan datanya.

d. Dokumen (berkas-berkas lama)

Di TVRI Stasiun Aceh di dalam setiap pengolahan datanya dicatat dalam buku, sehingga didalam pencarian arsip yang lama jika dibutuhkan akan mengalami kesulitan.

e. Laporan 
Sistem informasi pengelolaan program dan acara Pada TVRI Stasiun Aceh yang lama, laporan yang dihasilkan belum terformat atau tersusun dengan rapi, sehingga kurang bisa untuk digunakan sebagai sarana dalam pengambilan keputusan.

Analisis masukan merupakan data yang masuk kedalam system informasi. Komponen ini perlu ada karena merupakan bahan dasar dalam pengolahan data, adapun data-data tersebut adalah :
a. Nama Acara;
b. Nama Program;
c. Uraian;
d. Tanggal;
e. Kategori;
f. Pukul; dan
g. Keterangan

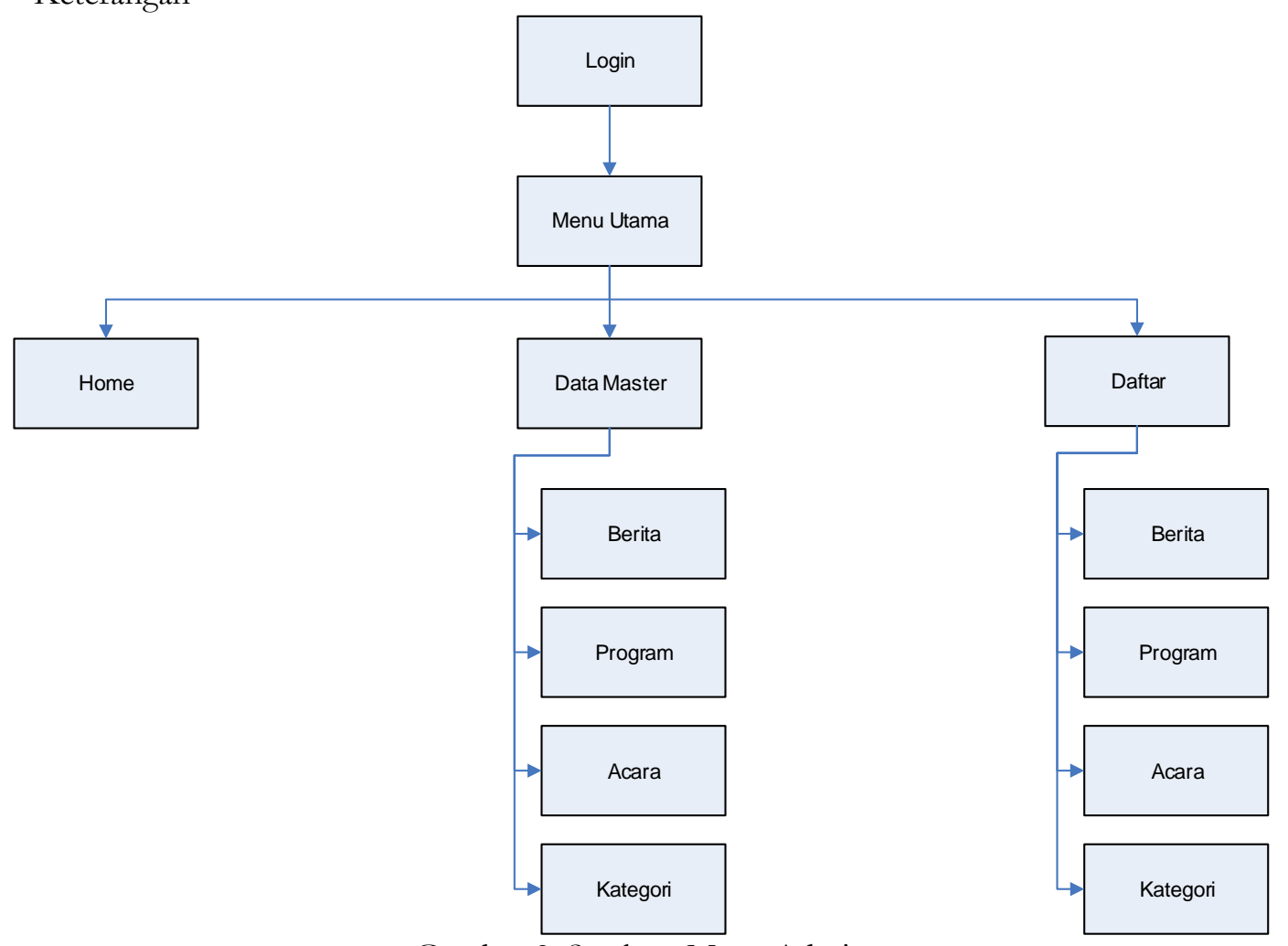

Gambar 2. Struktur Menu Admin 


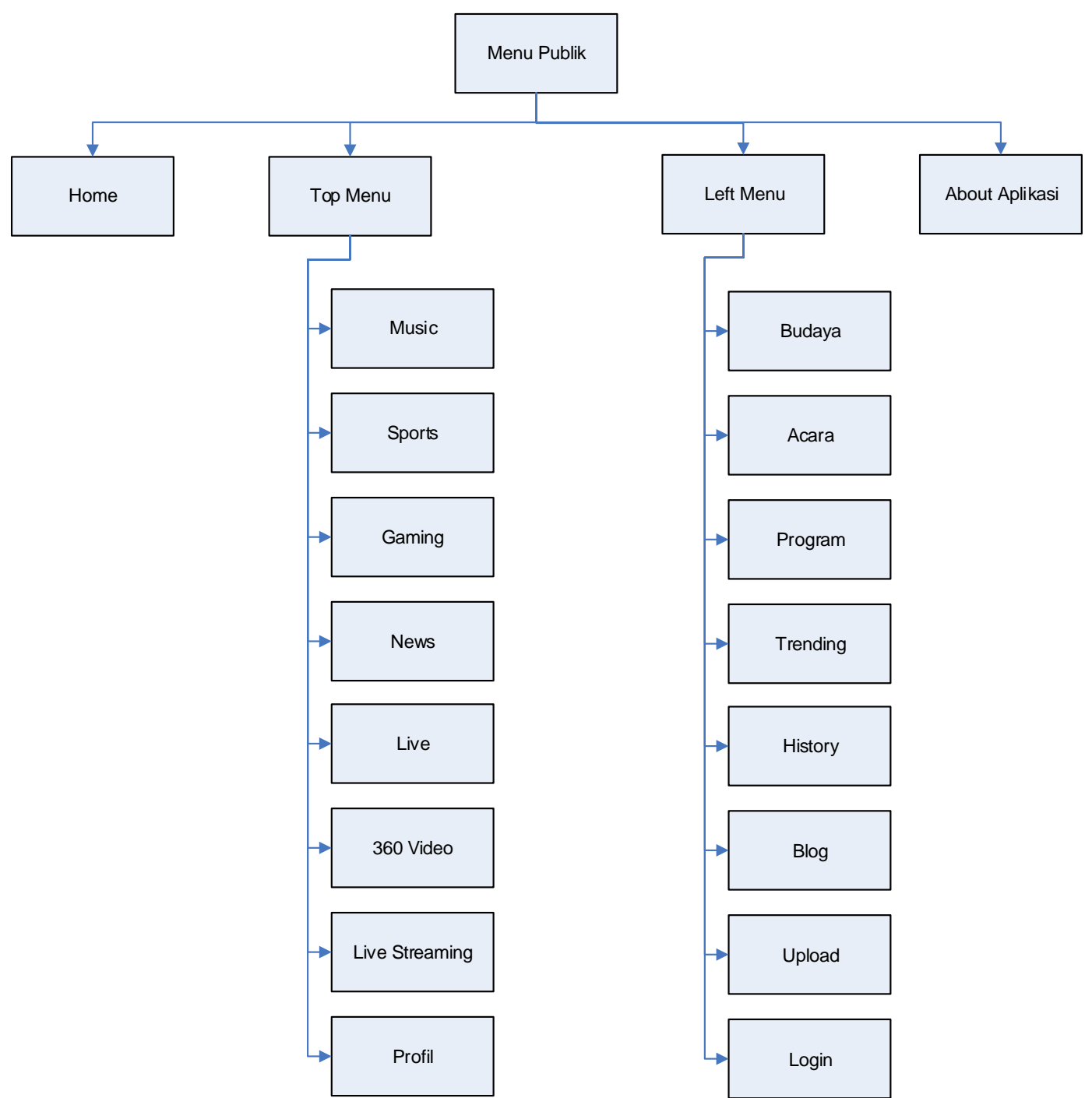

Gambar 3. Struktur Menu Publik

Proses pendataan program dan acara pada TVRI Stasiun Aceh pada dasarnya telah menggunakan komputer. pendataan program dan acara, selanjutnya bagian admnistrasi atau tata usaha mengirimkan form program dan acara khususnya bagi program dan acara untuk mengisi data kelengkapan lainnya. Selanjutnya setelah semua data lengkap, bagian administrasi membuat laporan rekapitulasi mengenai program dan acara tersebut, Agar lebih jelas sistem pendataan program dan acara dapat dilihat pada flowchart login, flowchart menu utama, flowchart input program dan acara, flowchart pencarian program dan acara, dan flowchart laporan rekap program dan acara sebagai berikut. 


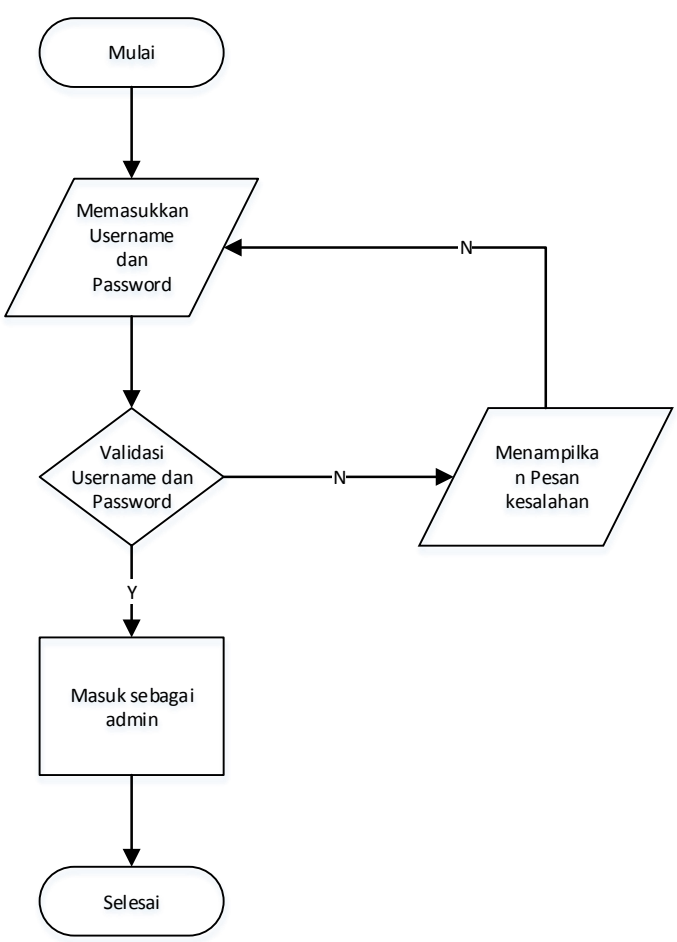

Gambar 4. Flowchart Login

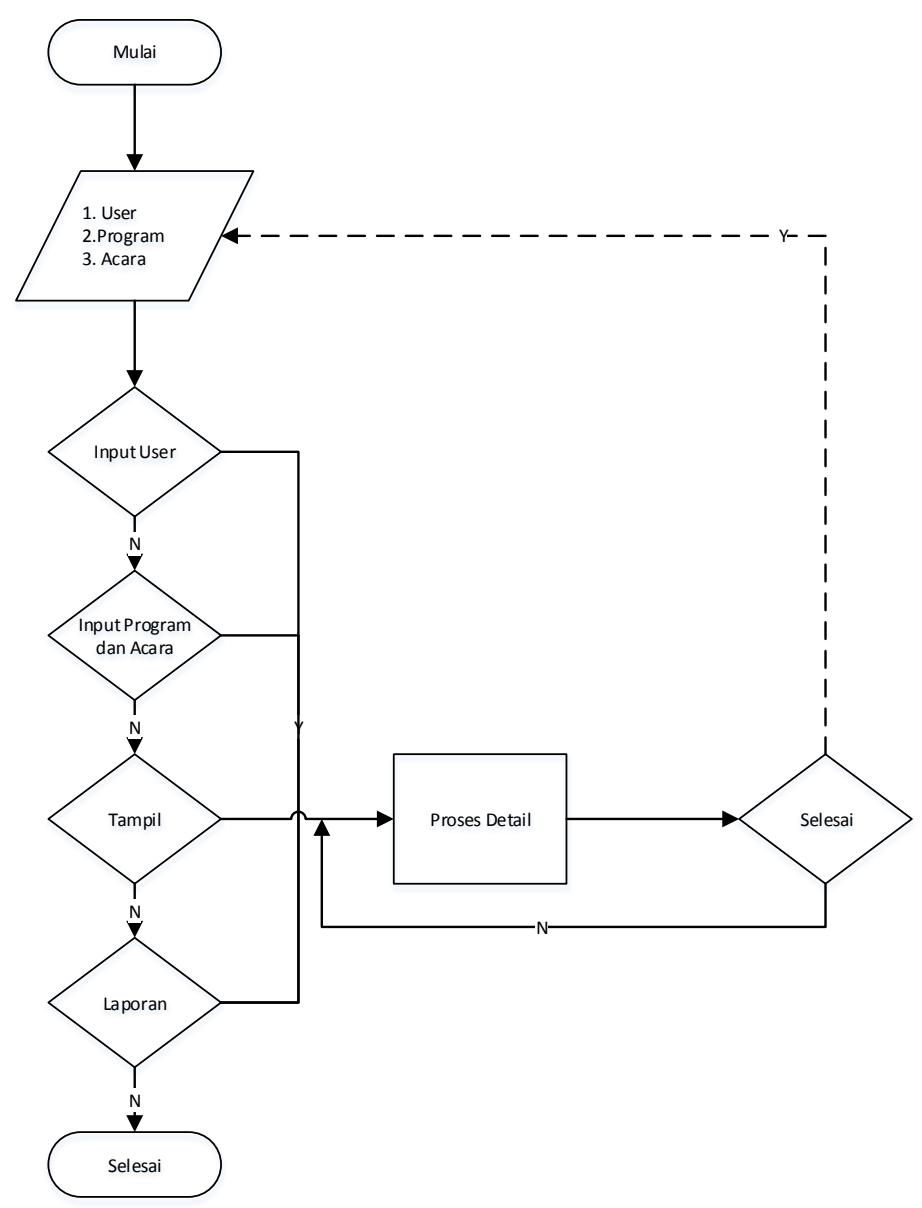

Gambar 5. Flowchart Menu Utama 
Jurnal Indonesia : Manajemen Informatika dan Komunikasi

www.journal.amikindonesia.ac.id/jimik/

Vol 2 No 1, Januari-Juni (2021)

E-ISSN: 2723-7079, P-ISSN: 2776-8074

Adapun hasil dari penelitian ini berupa sebuah aplikasi yang terdiri dari beberapa form yaitu; login, admin, input alat berat, penyewa, transaksi, dan user.

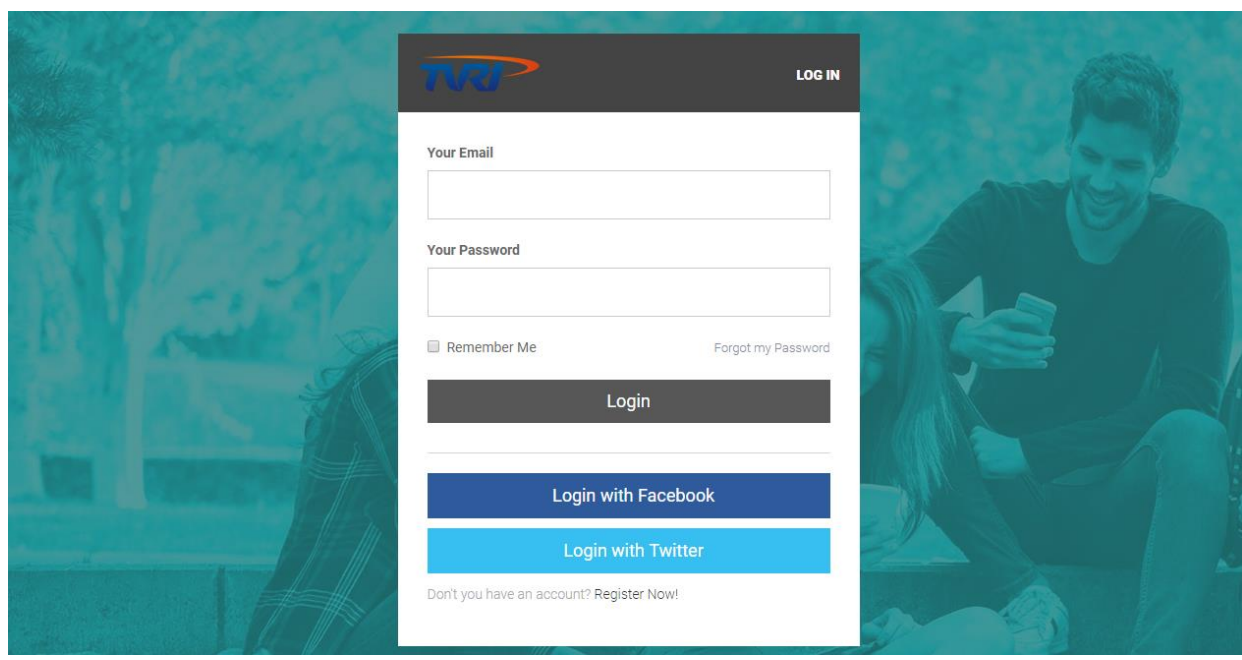

Gambar 6. Form Login

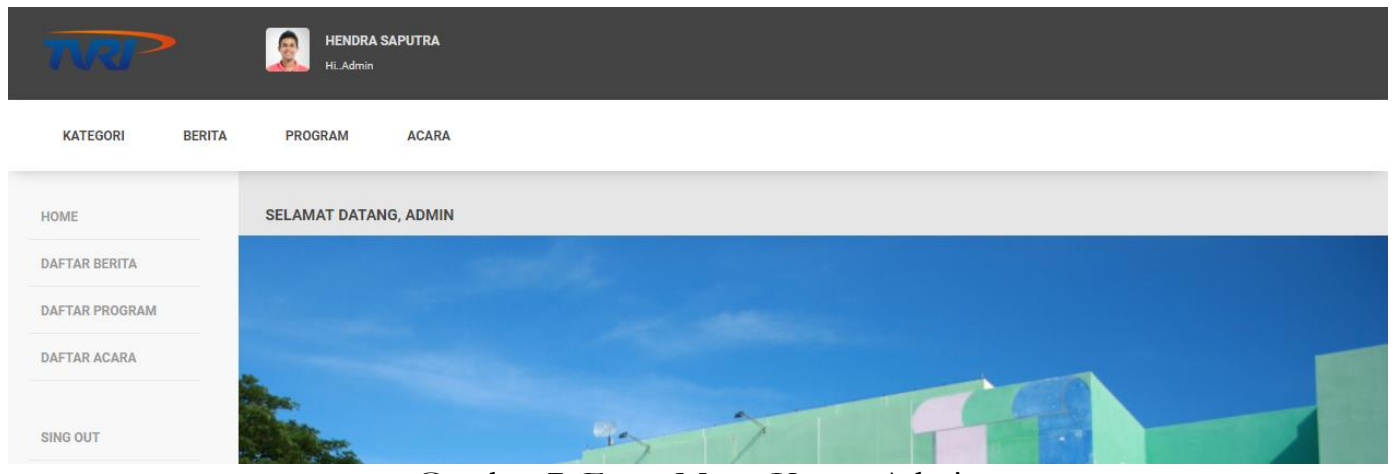

Gambar 7. Form Menu Utama Admin

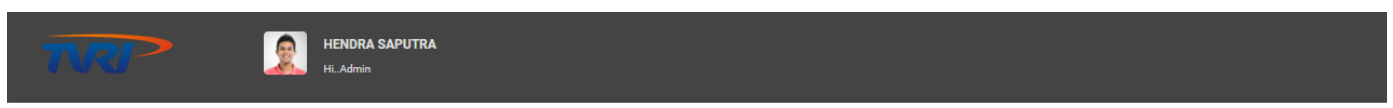

KATEGORI BERTA PROGRAM ACARA

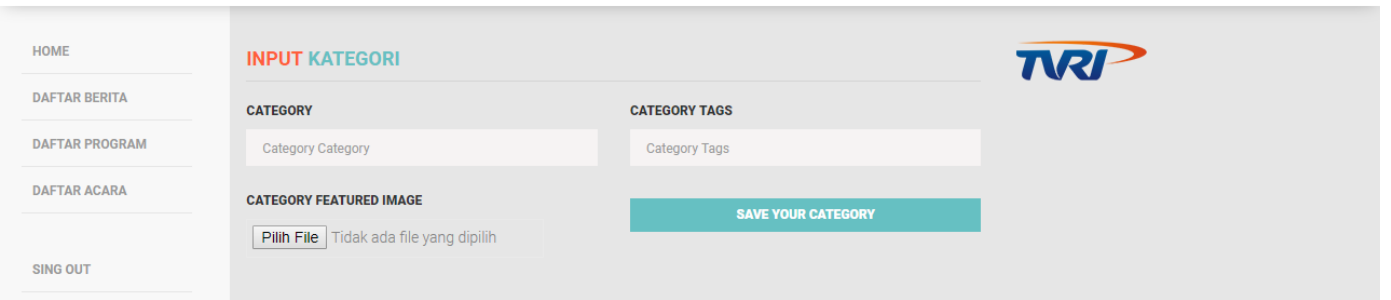

Gambar 8. Form Input Kategori 
Jurnal Indonesia : Manajemen Informatika dan Komunikasi

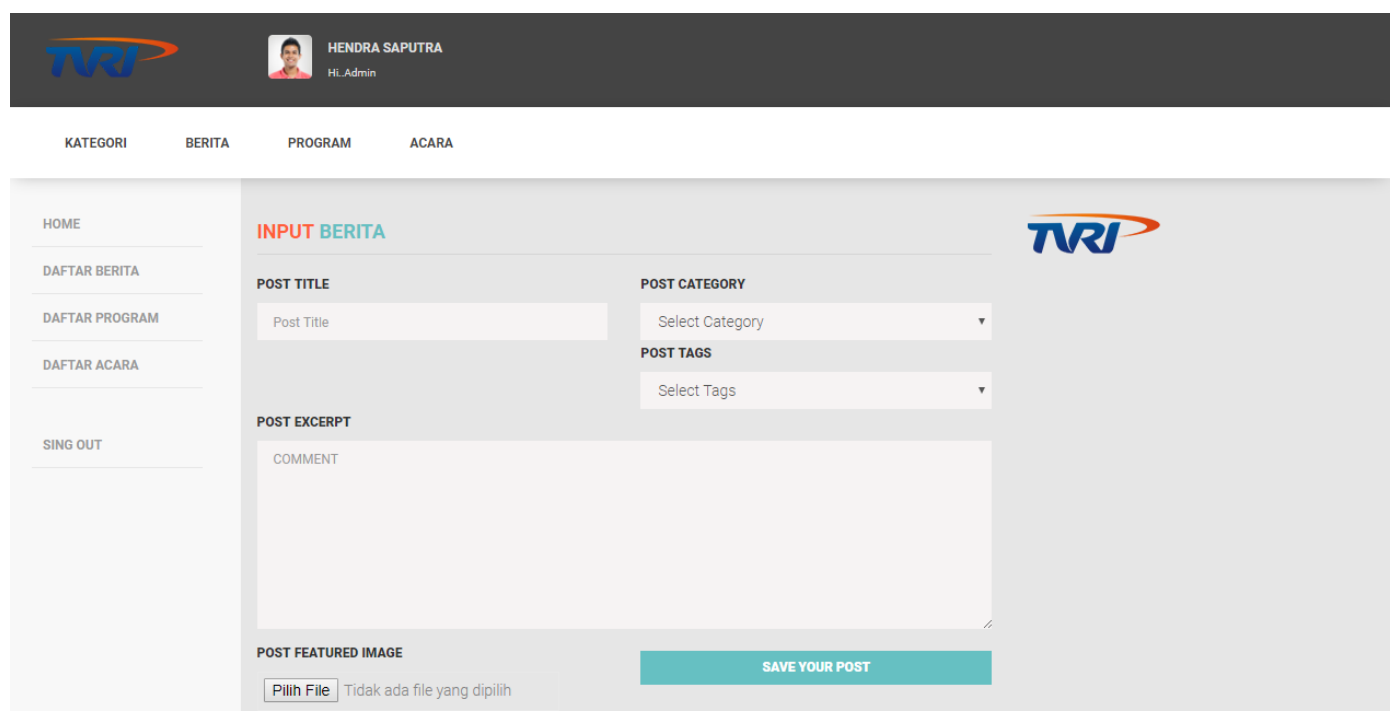

Gambar 9. Form Input Berita

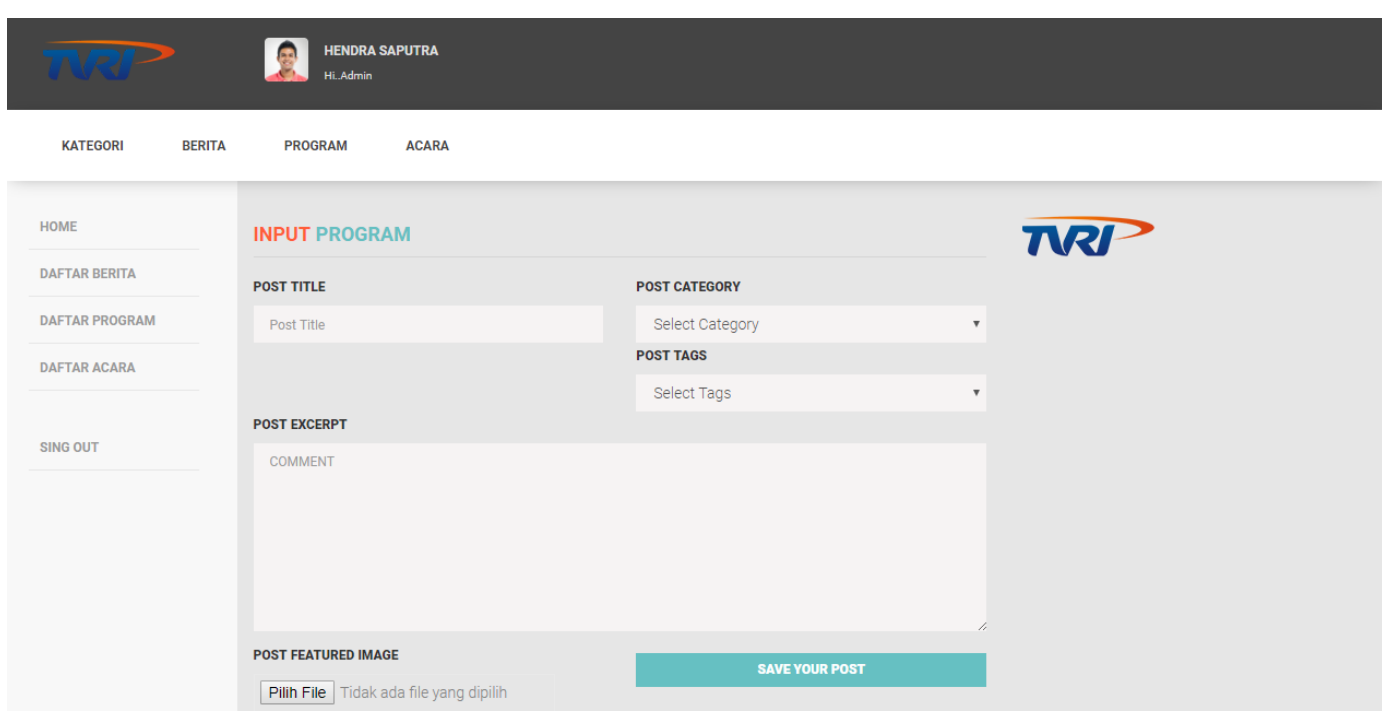

Gambar 10. Form Input Program

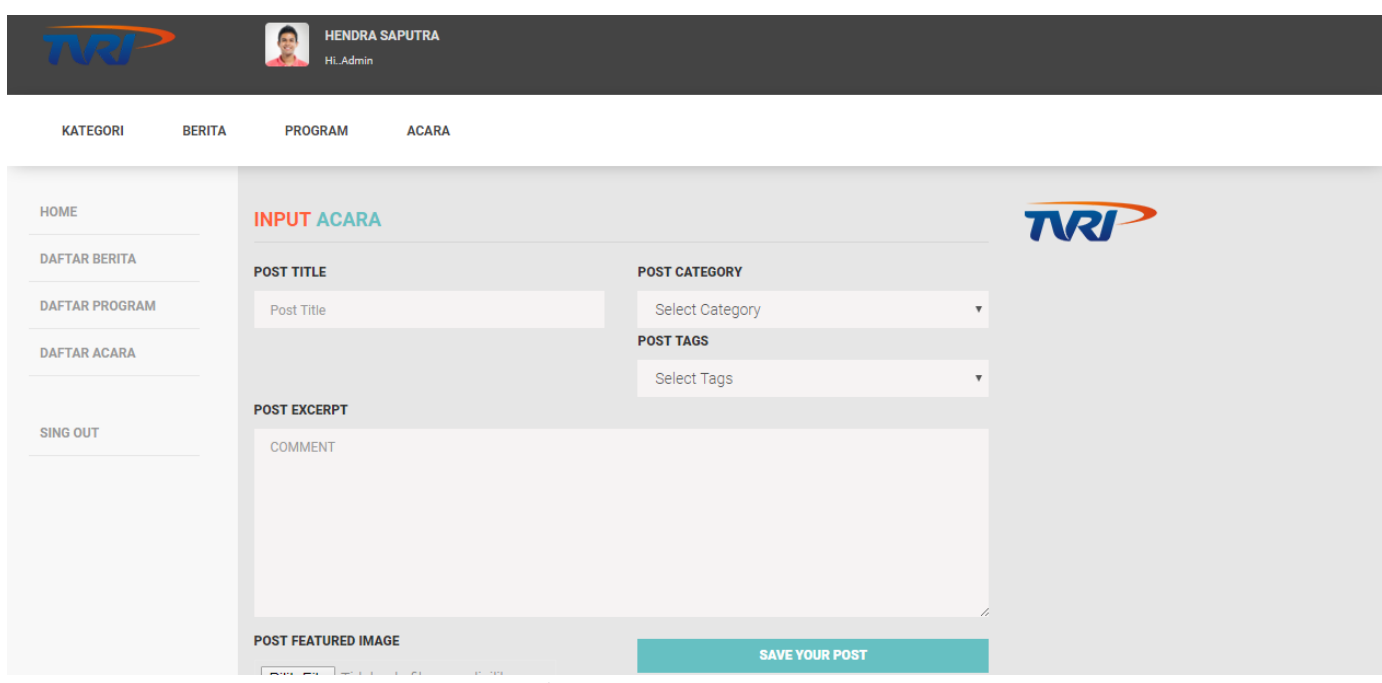

Gambar 11. Form Input Acara 
Sedangkan pada hasil laporan aplikasi terdiri dari; Form Laporan Berita, Program, dan Acara. Seperti terlihat pada gambar 12 sampai dengan 14 berikut.

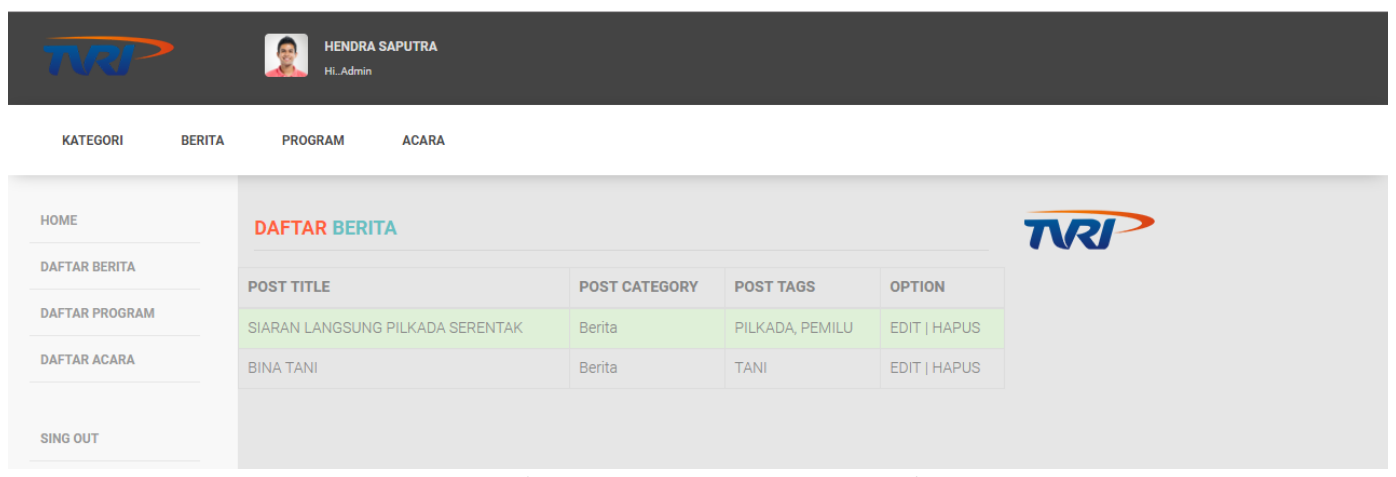

Gambar 12. Form Laporan Berita
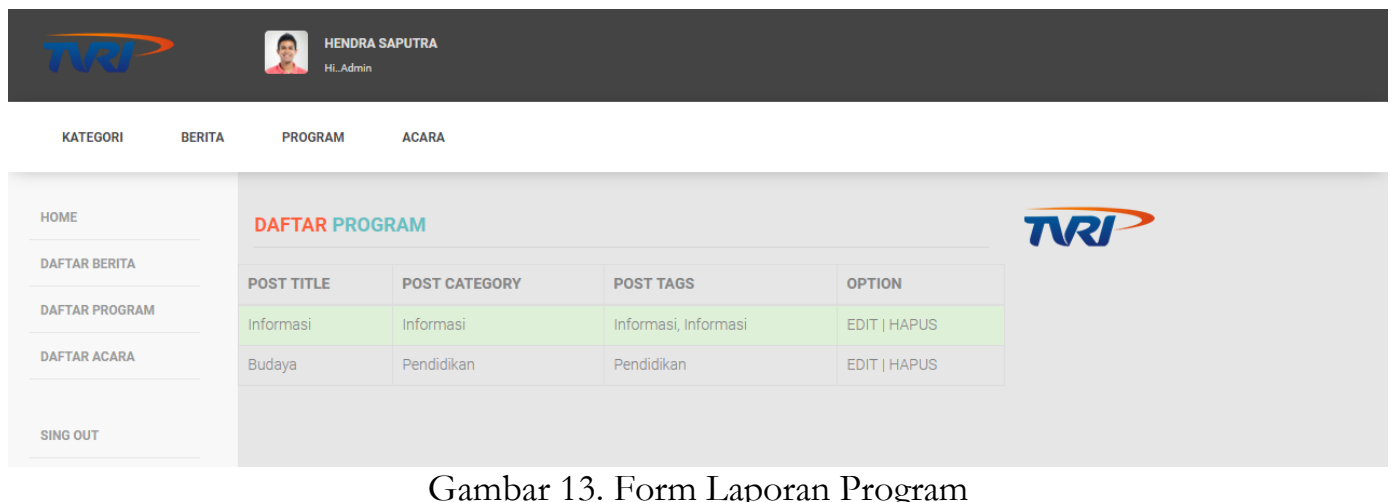

Gambar 13. Form Laporan Program
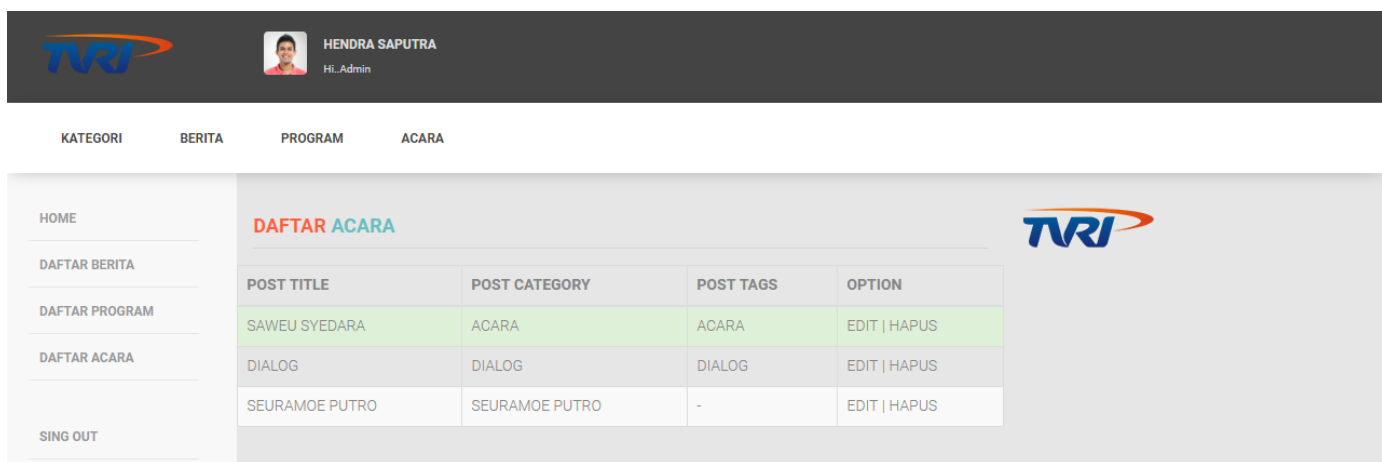

Gambar 14. Form Laporan Acara

Sedangkan pada hasil aplikasi yang ditampilkan pada halaman publik terdiri dari; halaman depan/ awal pengunjung, Musik, Live Streaming, profil, dan hubungi kami seperti terlihat pada gambar 15 sampai dengan 23 berikut ini. 
Jurnal Indonesia : Manajemen Informatika dan Komunikasi

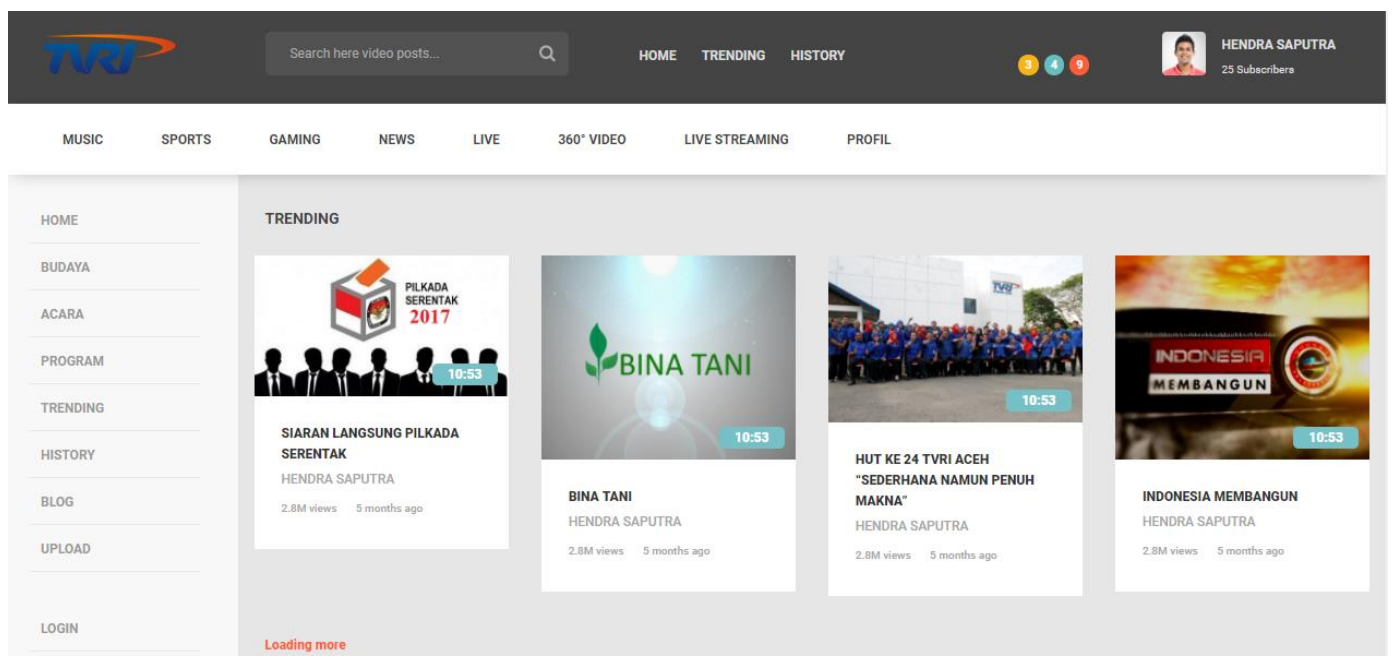

Gambar 15. Halaman Publik

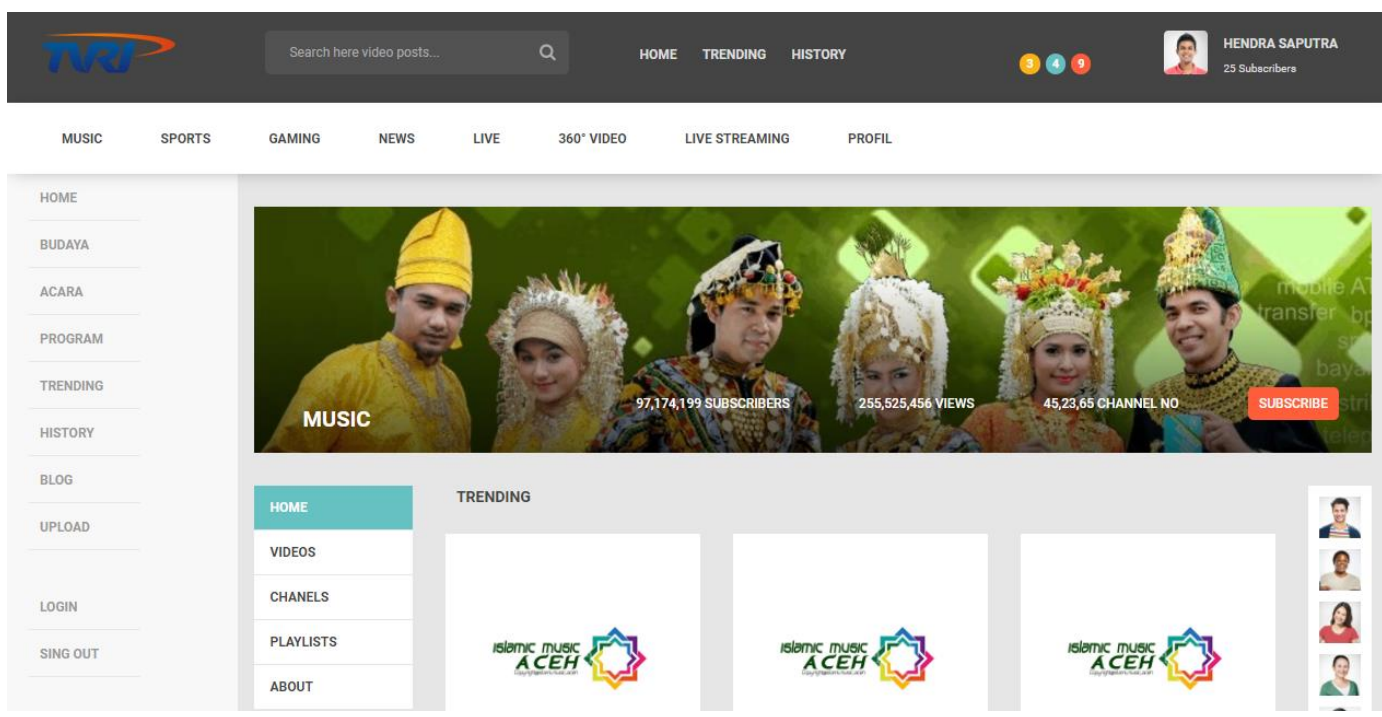

Gambar 16. Halaman Publik Musik

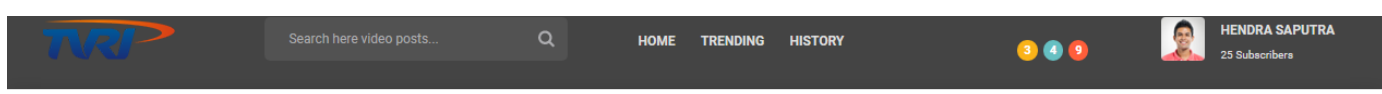

$\begin{array}{lllll}\text { MUSIC SPORTS GAMING NEWS LIVE } 360^{\circ} \text { VIDEO LIVE STREAMING PROFIL } & \text {. }\end{array}$

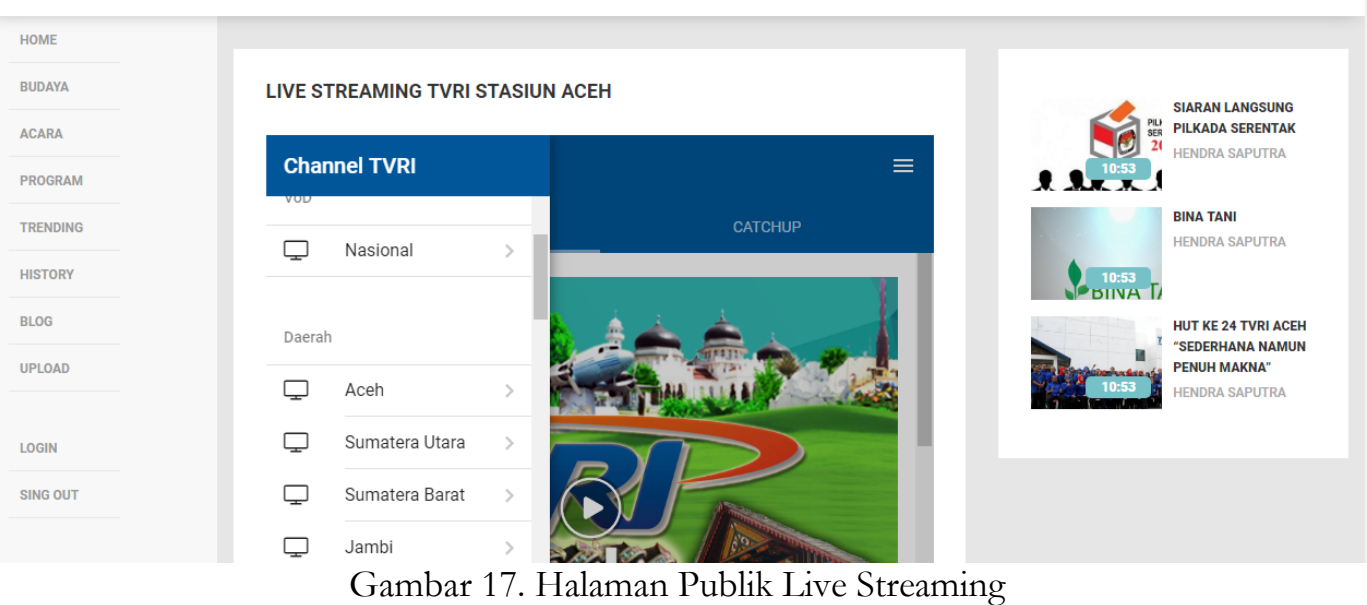

Gambar 17. Halaman Publik Live Streaming 
Jurnal Indonesia : Manajemen Informatika dan Komunikasi

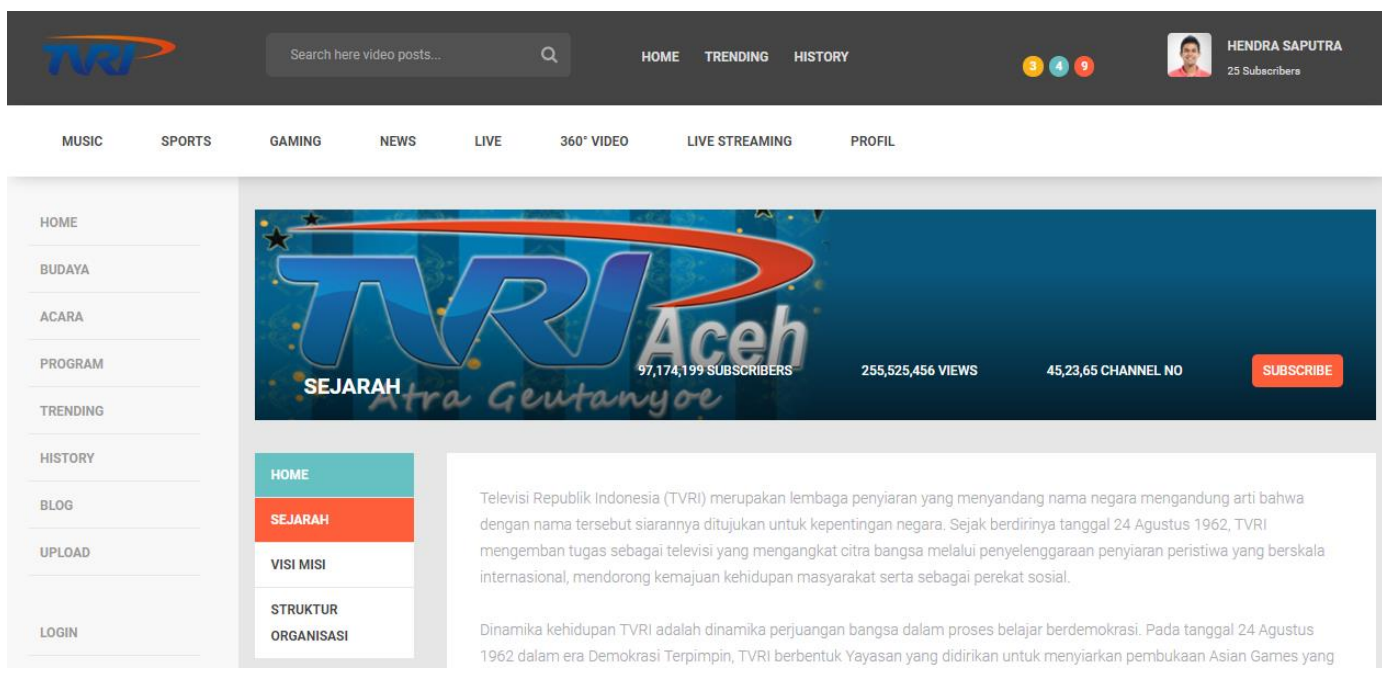

Gambar 18. Halaman Publik Profil Sejarah
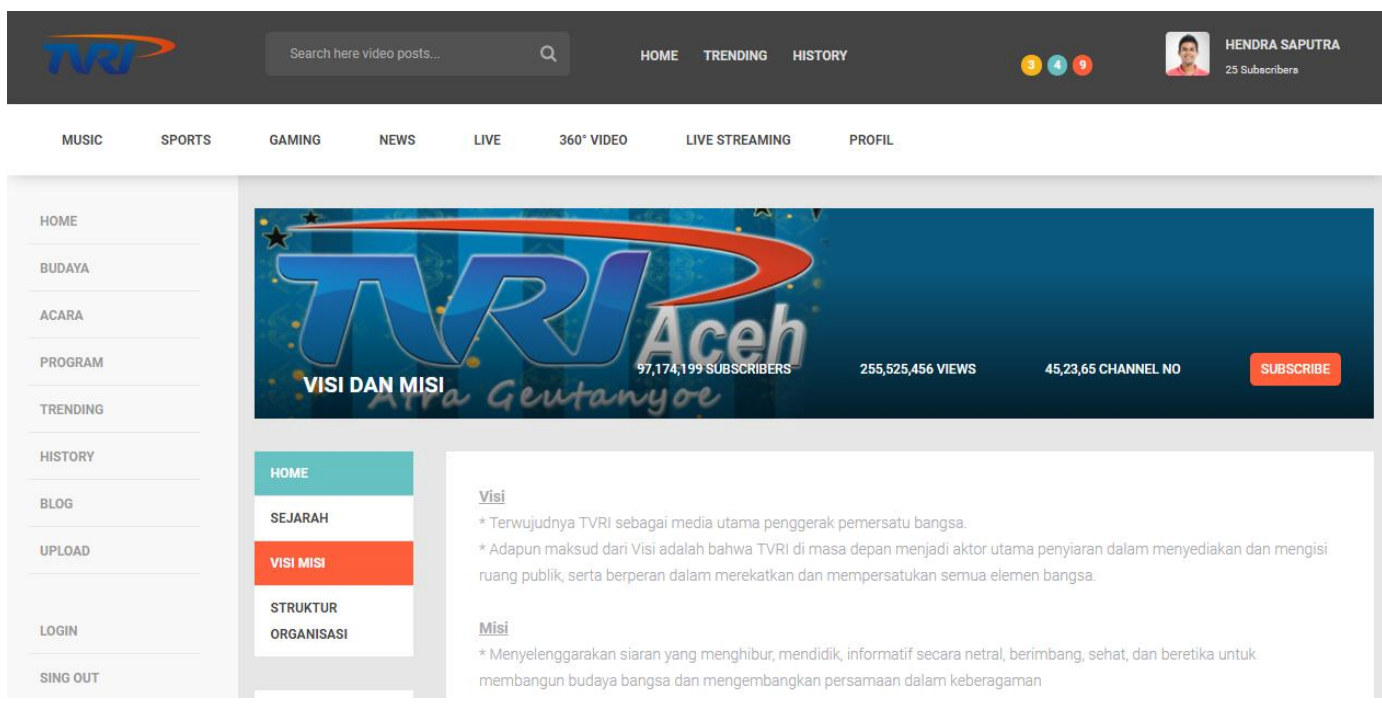

Gambar 19. Halaman Publik Profil Visi Misi

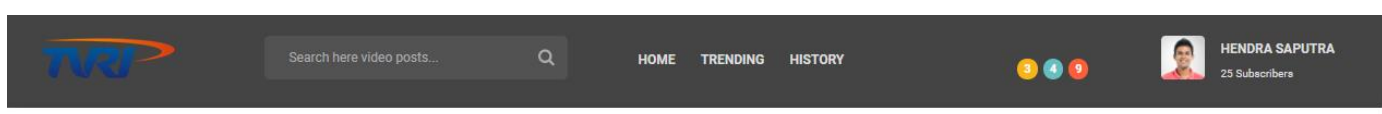

$\begin{array}{lllllll}\text { MUSIC SPORTS GAMING NEWS LIVE } & 360^{\circ} \text { VIDEO } & \text { LIVE STREAMING PROFL }\end{array}$

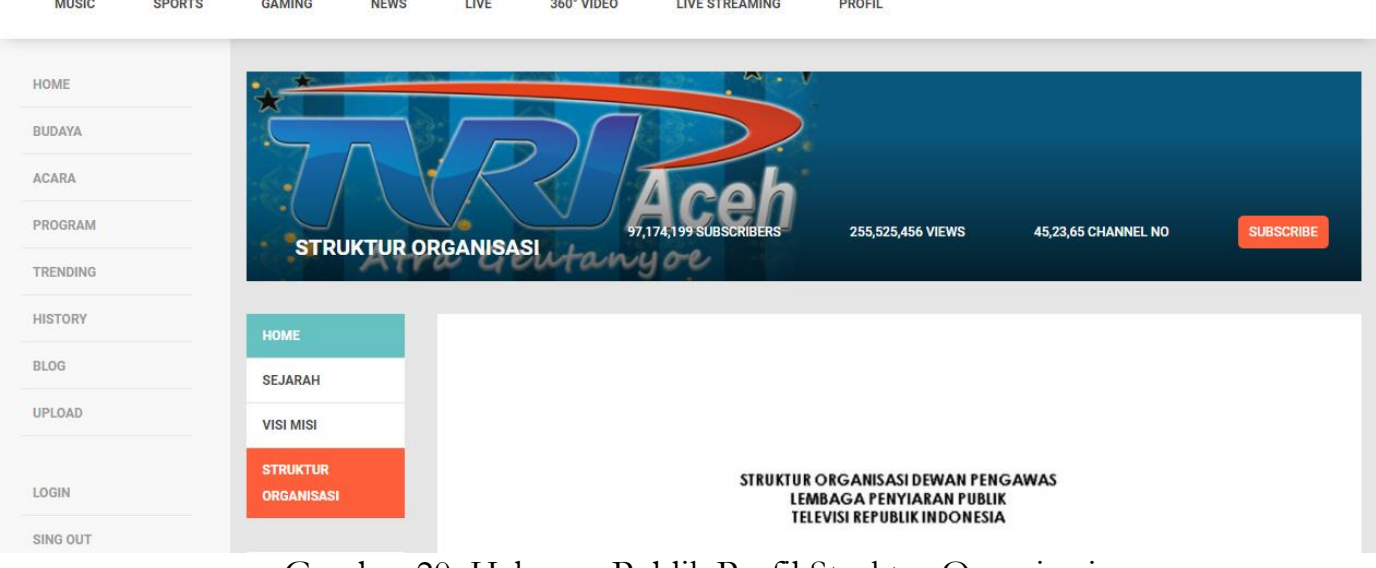

Gambar 20. Halaman Publik Profil Struktur Organisasi 
Jurnal Indonesia : Manajemen Informatika dan Komunikasi

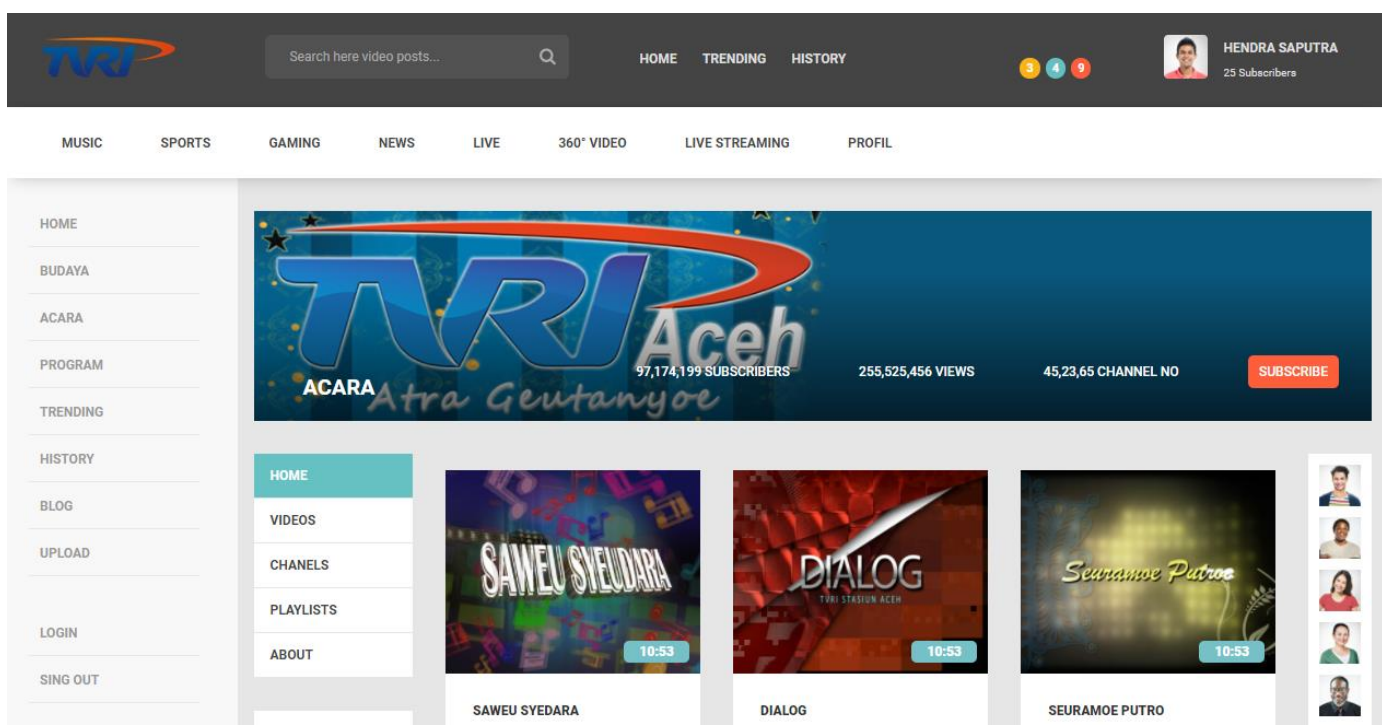

Gambar 21. Halaman Publik Acara

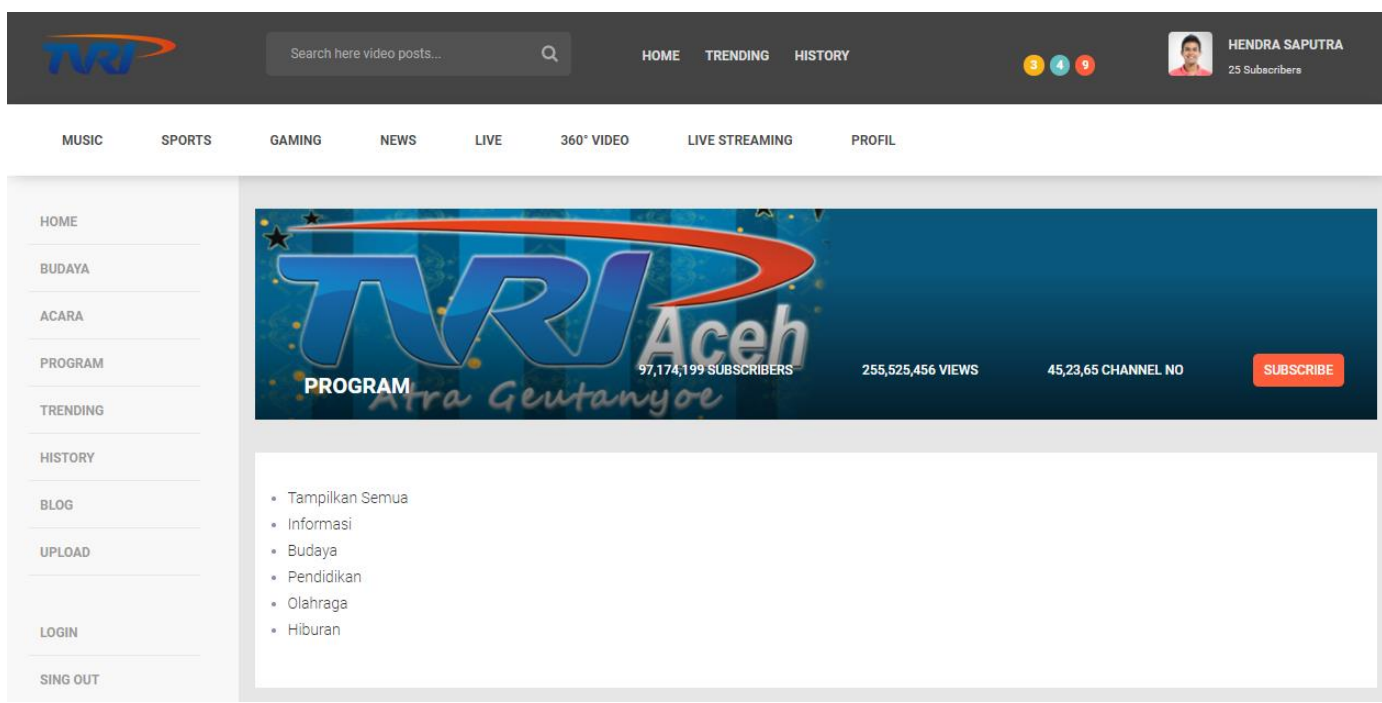

Gambar 22. Halaman Publik Program

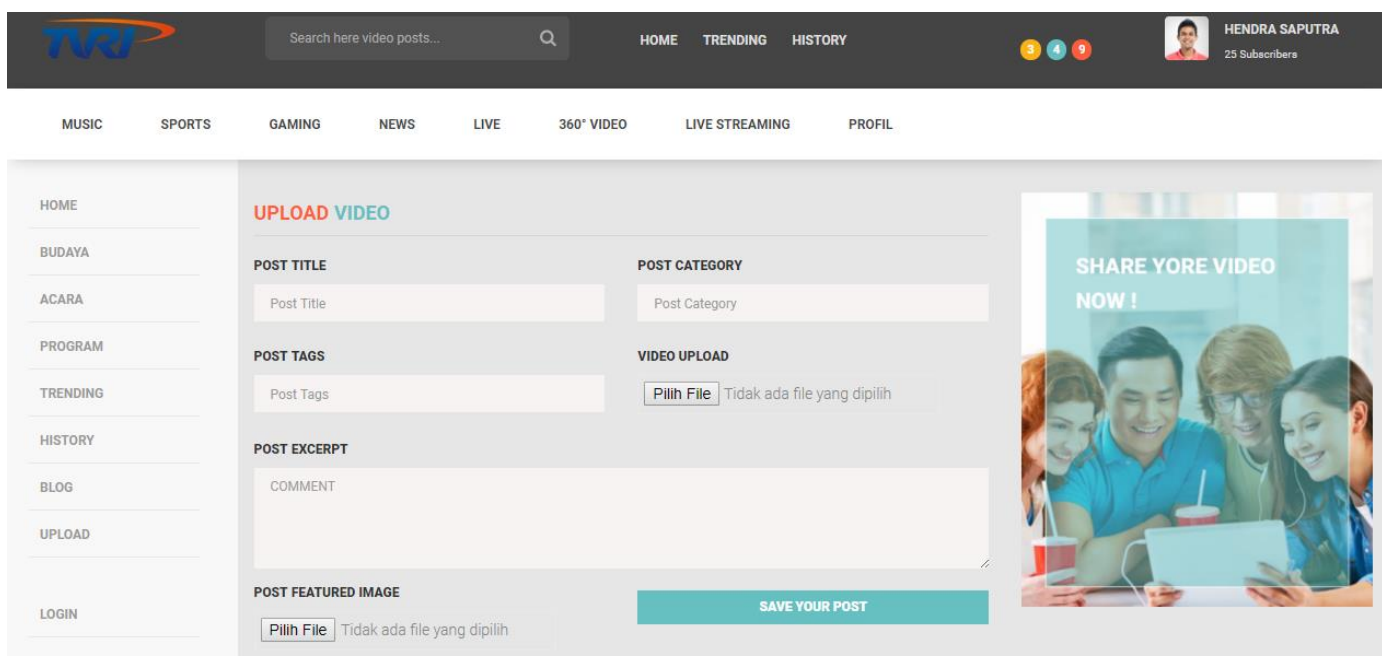

Gambar 23. Halaman Publik Upload Video 
Berikut ini adalah hardware dan software yang dibutuhkan untuk menggunakan program sistem program dan acara, yaitu:

a. Hardware

Hardware yang dapat mendukung aplikasi ini memerlukan perangkat keras dengan spesifikasi:

1. CPU minimal pentium 3 dengan kecepatan $633 \mathrm{Mhz}$

2. Ram $256 \mathrm{MB}$

3. Hard disk minimal 1 GigaByte

4. Monitor

5. Keyboard dan Mouse

6. Printer

\section{b. Software}

Software yang mendukung aplikasi ini diantaranya:

1. Windows 7,8,10, Linux, Symbian, Android

2. Browser (Mozilla, Google Chrome)

3. Xampp.

\section{Kesimpulan}

Berdasarkan hasil pengamatan dan penulis dapat menarik suatu kesimpulan yang diantaranya adalah sebagai berikut :

a. Dalam mengolah data program dan acara, masih menggunakan pencatatan pada arsip atau buku, sehingga dapat mengurangi pelayan yang diberikan kepada program dan acara. Sebagai contoh, dalam proses pencarian data program dan acara membutuhkan waktu yang cukup lama, jika program dan acara yang datang jumlahnya cukup banyak maka waktu tunggu semakin lama, tentu saja hal ini akan membuat program dan acara merasa kurang dipedulikan dan kurang dilayani dengan baik. Data yang tersimpan dalam bentuk arsip atau buku, mempunyai resiko kehilangan dan kerusakan cukup tinggi, misal terbakar, terkena air, kertasnya robek dan hal lainnya. Data merupakan hal yang penting karena didalamnya terdapat data program dan acara, rawat laporan program dan acara dan hal-hal yang lain menyangkut laporan program dan acara. Untuk itu diperlukan sebuah solusi sistem yang terkomputerisasi untuk mengatasi masalahmasalah tersebut.

b. Berikut beberapa kelebihan yang didapat dari sistem yang telah terkomputerisasi dari sistem pencatatan pada arsip atau buku, antara lain:

1. Untuk pengolahan dan pencatatan data dapat dilakukan dengan lebih baik, sehingga dapat mempersingkat waktu pengolahan data tersebut.

2. Proses pencarian data dapat dilakukan dengan cepat, sehingga waktu tunggu program dan acara menjadi singkat, maka setiap instansi membutuhkan layanan laporan program dan acara yang datang bisa mendapatkan pelayanan yang prima.

3. Memudahkan dalam pembutan laporan, baik laporan data program dan acara. Dengan fasilitas ini, maka laporan dapat dibuat dengan cepat, dan tepat serta rapi.

4. Dari keamanan data yang disimpan dalam sistem yang terkomputerisasi mempunyai tingkat keamanan yang tinggi karena dilengkapi dengan verifikasi pengguna (login user), sehingga hanya orang yang mempunyai hak akses saja yang dapat menggunakan.

5. Resiko kerusakan atau kehilangan data dalam sistem komputerisasi masih tetap ada, namun dalam skala yang relatif rendah. Untuk mengatasi hal ini dapat dilakukan backup data ke tempat penyimpanan lain selain harddisk komputer. 


\section{Daftar Pustaka}

[1] Nur, E., 2021. Peran Media Massa Dalam Menghadapi Serbuan Media Online. Majalah Semi Ilmiah Populer Komunikasi Massa, 2(1).

[2] Khatimah, H., 2018. Posisi dan Peran Media dalam Kehidupan Masyarakat. TAS AMUH, 16(1), pp.119-138.

[3] Hendra, T., 2019. Media Massa Dalam Komunikasi Pembangunan. JURNAL ATTAGHYIR, 1(2), pp.136-152.

[4] Kholisoh, N., 2018. Pengaruh Terpaan Informasi Vlog di Media terhadap Sikap Guru dan Dampaknya terhadap Persepsi Siswa. Jurnal Aspikom, 3(5), pp.1002-1014.

[5] Wali, M., 2017. Adsense Mobile dan Respon Pengguna Smartphone: Intrusiveness dan Irritation. Jurnal EMT KITA, 1(2), pp.107-120.

[6] Bahua, M.I., 2018. Perencanaan Partisipatif Pembangunan Masyarakat. Gorontalo: Ideas Publishing.

[7] Rizal, S., 2019. Faktor-Faktor yang mempengaruhi Kepuasan Konsumen dan Kaitannya Dengan Kesetiaan Merek pada Produk Kesehatan K-Link di Kota Banda Aceh. Jurnal EMT KITA, 3(2), pp.85-93.

[8] Nasir, N., Zakaria, Z. and Yuslinaini, Y., 2019. Standarisasi Kepuasan Wisatawan Pengguna Jasa Taman Rusa Lamtanjong Aceh Besar dan beberapa Faktor yang Mempengaruhinya. Jurnal EMT KITA, 3(2), pp.70-80.

[9] Dahlan, D. and Yusra, Y., 2018. Model Revitalisasi Modal Sosial Guna Meningkatkan Pelaksanaan Fungsi Anggota Dewan Perwakilan Rakyat. Jurnal EMT KITA, 2(1), pp.9-18.

[10] Nisa, Z.A., 2020. Komodifikasi budaya dalam tayangan program berita di telivisi lokal: Analisis wacana kritis model Norman Fairclough pada tayangan program berita Pawartos Pantura Citra TV (Doctoral dissertation, UIN Sunan Gunung Djati Bandung).

[11] Yulianti, H.D. and Masduki, M., 2008. Analisis Model Produksi Berita Televisi Lokal: Studi TVRI Stasiun Penyiaran Kalimantan Selatan dan Banjar TV. Jurnal Komunikasi, 3(1), pp.101114.

[12] Ardiyanti, H., 2016. Konsep dan regulasi tv lokal dalam kerangka penguatan budaya lokal. Jurnal Politica Dinamika Masalab Politik. Dalam Negeri dan Hubungan Internasional, 2(2).

[13] Ainiyyah, A., 2021. Penerapan Tema High-tech Architecture pada Perancangan Gedung Stasiun TVRI Aceh. Jurnal Ilmiah Mahasiswa Arsitektur dan Perencanaan, 5(1), pp.6-11. 
[14] SABARINO, A., 2018. Pengaruh Pelayanan Dan Inovasi Terhadap Ekuitas Merek Serta Dampaknya Terhadap Loyalitas Pemirsa Tvri Aceh. ETD Unsyiah.

[15] Amelia, C.N., 2017. Perkembangan Siaran Televisi Dan Perannya Dalam Bidang Pendidikan Di Aceh (1982-2015). ETD Unsyiah.

[16] Kristanty, S. and Ramadhan, G.A., 2021. Penerapan Strategi Kreatif Dalam Mempertahankan Program "Buah Hatiku Sayang" di Televisi Republik Indonesia. Communication, 12(1), pp.21-33.

[17] Putra, A.P., Shintya, Z. and Arisanty, M., 2019. Strategi Programming Program "Metro Pagi Primetime" Dalam Mempertahankan Rating. Jurnal Common, 3(1), pp.1-25.

[18] Octaviani, L.Y., 2019. strategi manajemen penyiaran aditv sebagai stasiun televisi lokal bernuansa islami (Doctoral dissertation, Institut Seni Indonesia (ISI) Surakarta).

[19] Anggara, A.W., 2020. Sistem Informasi Pendataan Alat Bantu Bagi Penyandang Disabilitas Pada Dinas Sosial Aceh. Jurnal Indonesia: Manajemen Informatika dan Komunikasi, 1(2), pp.5562.

[20] Cahya, N., 2020. Perancangan Sistem Informasi Absensi Karyawan Pada Kantor Satpol Pp Dan Wh Aceh. Jurnal Indonesia: Manajemen Informatika dan Komunikasi, 1(2), pp.63-69.

[21] MYSQL, A., 2020. Pembuatan E-Library Di Balai Bahasa Provinsi. Jurnal Indonesia: Manajemen Informatika dan Komunikasi, 1(2), pp.63-72.

[22] Iqbal, T., 2019. Perancangan Repository Dengan Dukungan Open Archieve Initiative (Oai) Berbasis Open Source Menggunakan Codeigniter Dan Node. Js. Smart Comp: Jurnalnya Orang Pintar Komputer, 8(2), pp.57-62.

[23] Iqbal, T., Aprizal, D. and Wali, M., 2017. Aplikasi Manajemen Persediaan Barang Berbasis Economic Order Quantity (EOQ).Jurnal JTIK Jurnal Teknologi Informasi dan Komunikasi), 1(1), pp.48-60.

[24] Ismail, I. and AlBahri, F.P., 2019. Perancangan E-Kuisioner menggunakan CodeIgniter dan React-Js sebagai Tools Pendukung Penelitian. J-SAKTI Jurnal Sains Komputer dan Informatika), 3(2), pp.337-347.

[25] Safrinal, S., Sukendi, I., Supriyanto, S. and Afrizal, A., 2021. Use of a Webpage in Designing Employee Data Collection at the Aceh Language Center Office. International Journal Software Engineering and Computer Science (IJSECS), 1(1), pp.1-6.

[26] Zulkhaida, K., Henryanto, Y. and Jaenuddin, H., 2021. Information Systems Inventory of Goods in The Warehouse at PT. Transvision. International Journal Software Engineering and Computer Science (IJSECS), 1(1), pp.7-12. 
Jurnal Indonesia : Manajemen Informatika dan Komunikasi

www.journal.amikindonesia.ac.id/jimik/

Vol 2 No 1, Januari-Juni (2021)

E-ISSN: 2723-7079, P-ISSN: 2776-8074

[27] Sadharma, D.E., 2021. Design of Asset Collection Information System Based on Website. International Journal Software Engineering and Computer Science (IJSECS), 1(1), pp.21-33.

[28] Nasikin, K., 2012. Pengembangan Sistem Informasi Akademis Dan Keuangan Di MAN 2 Pati. Speed-Sentra Penelitian Engineering dan Edukasi, 3(3). 